Debate

\title{
Iron: a target for the management of Kaposi's sarcoma? Thierry Simonart*
}

\author{
Address: Department of Dermatology, Erasme University Hospital, Route de Lennik 808, B-1070 Brussels, Belgium \\ Email: Thierry Simonart* - tsimonar@ulb.ac.be \\ * Corresponding author
}

Published: 15 January 2004

BMC Cancer 2004, 4: I
Received: 28 October 2003

Accepted: 15 January 2004

This article is available from: http://www.biomedcentral.com/I47/-2407/4/I

(c) 2004 Simonart; licensee BioMed Central Ltd. This is an Open Access article: verbatim copying and redistribution of this article are permitted in all media for any purpose, provided this notice is preserved along with the article's original URL.

\begin{abstract}
Background: Kaposi's sarcoma (KS) is a mesenchymal tumour associated with human herpesvirus-8 infection. However, the incidence of human herpesvirus-8 infection is far higher than the prevalence of KS, suggesting that viral infection per se is not sufficient for the development of malignancy and that one or more additional cofactors are required.
\end{abstract}

Discussion: Epidemiological data suggest that iron may be one of the cofactors involved in the pathogenesis of KS. Iron is a well-known carcinogen and may favour KS growth through several pathways. Based on the apoptotic and antiproliferative effect of iron chelation on KS cells, it is suggested that iron withdrawal strategies could be developed for the management of KS. Studies using potent iron chelators in suitable KS animal models are critical to evaluate whether iron deprivation may be a useful anti-KS strategy.

Summary: It is suggested that iron may be one of non-viral co-factors involved of KS pathogenesis and that iron withdrawal strategies might interfere with tumour growth in patients with KS.

\section{Background}

Kaposi's sarcoma (KS) is a mesenchymal tumour that has been identified in different clinical/epidemiological settings: classic KS, an indolent form usually found in elderly men of Mediterranean or Eastern European origin; African-endemic KS, which usually involves the lower extremities (figure 1) and which existed well before the HIV epidemic in some equatorial countries of Africa; immunosuppressive drug-related KS; AIDS-associated KS and HIVnegative gay-related KS. All these forms of KS share a similar histopathology characterised by the proliferation of spindle-shaped cells, by neoangiogenesis, by erythrocyte extravasation and by the presence of haemosiderin-laden macrophages and other inflammatory cells.

A large body of evidence indicates that human herpesvirus-8 (HHV-8) has an important etiologic role in the pathogenesis of KS; 1) HHV-8 can be detected in all the epidemiological and histological forms of KS [1-3] and can directly infect the KS spindle cells $[4,5]$; 2) HHV-8 encodes several genes that can independently transform cells to a malignant phenotype [6]; 3) infection precedes development of the tumour and tracks tightly with KS risk [3]. However, HHV-8 infection appears as a very low risk factor for KS development. Most reports suggest a 2 to $10 \%$ global seroprevalence of HHV-8, with much higher rates in some areas $[7,8]$. Assuming a $5 \%$ prevalence of HHV-8 in the United States and a 1970s baseline incidence of KS in men in the United States of about 0.3 cases per 100000 men, the HHV-8 rate would be one case of KS in every 17000 HHV-8 infections [9]. In addition, seroprevalence rates in different geographic areas do not always correlate with KS development. Eighty-nine percent to $100 \%$ of serum samples from the general population in non-KS-endemic African areas such as Gambia or the Ivory Coast, proved to be positive; such a rate is higher 


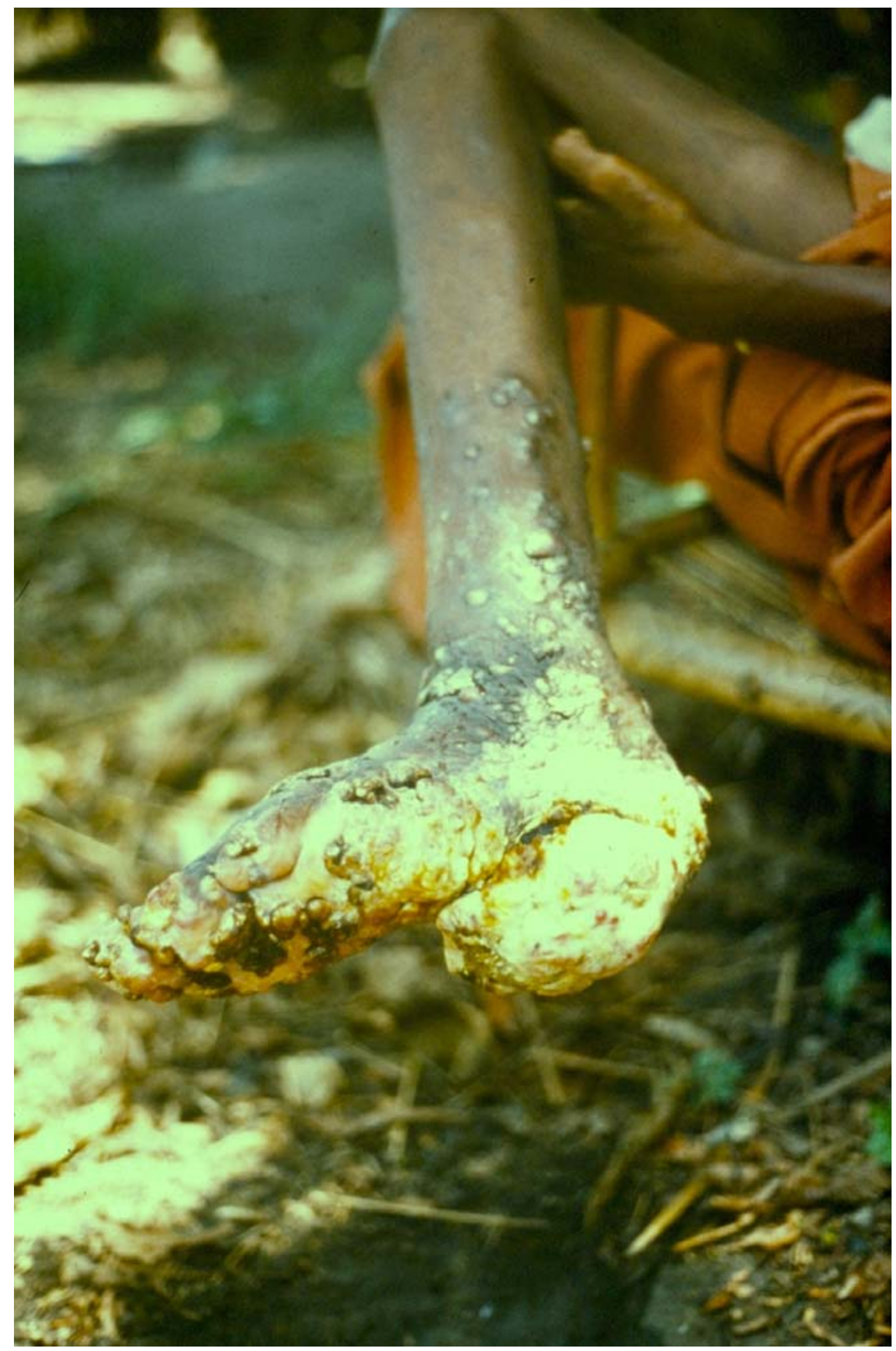

Figure I

Aggressive African-endemic KS of the foot. 
than the $40 \%$ rate found in sub-Saharan Africa, where KS is endemic [10]. A similar finding among Brazilian-Amerindians has been published; seroprevalence was 53\%, although KS has never been reported in this population [11]. Another puzzling finding is the similarity of rates of HHV-8 infection among men and women in Africa [10]. Since the KS found in Africa is about 8 to 10 times as common among men as among women, there must be some reason other than HHV-8 infection to explain this difference.

Thus, there is now compelling evidence that HHV-8 is a necessary, albeit not sufficient, cause of KS and that one or more additional cofactors are required. These co-factors may represent a target for the prevention and/or treatment of KS.

\section{Discussion \\ High incidence of $K S$ in iron oxide-rich volcanic clays}

Endemic KS in Africa predated the HIV epidemic and showed evidence of geographic restriction $[12,13]$, suggesting a genetic or an environmental cofactor. The highest prevalence of endemic KS in Africa lies in a broad strip running from the Uganda, Sudan, and Democratic Republic of Congo border southwards through Rwanda and Burundi. In the Northeastern provinces of the Democratic Republic of Congo, and in Rwanda and Burundi, KS accounts for up to $17 \%$ of adult male malignancies $[13,14]$. Prevalence diminishes rapidly away from this endemic region. Amazingly, these areas of high prevalence of endemic KS are characterised by a common geologic substratum, composed of iron oxide-rich volcanic clays (figure 2). This observation led Dr. Ziegler to suggest that chronic exposure to volcanic clays plays a role in the pathogenesis of African-endemic KS [14]. His intriguing hypothesis was that ultrafine particles of clay penetrate the skin of the feet during barefoot walking, leading to dermal lymphatic damage and to impaired local immunity. Further data have strengthened the hypothesis of soil exposure and percutaneous penetration of ferromagnetic particles as a risk factor for KS. More particularly, barefoot walking, time spent in contact with water and exposure to wet soils appear as important risk factors for KS in Uganda $[15,16]$. In water, a clay emulsion disaggregates into particles less than $2 \mu \mathrm{m}$, a size that can readily enter sweat glands of the feet [17]. While cultivating (especially in the rainy season when clay soils are pliant and workable), soil particles might thus enter the sweat glands and pores of the feet, perhaps aided by micro-abrasions caused by the high quartzite content of these soils. In this perspective, we have reported the case of a metallurgist with classic KS involving his palm. Iron filings were detected in the underlying cutaneous tissues by magnetic resonance imaging, supporting the hypothesis that percutaneous penetration of iron may favour the development of KS [18].

Exposure to volcanic clays may also help to explain the distribution of classic KS in the Mediterranean, prevalent in volcanic regions such as the Pelopenese, Sardinia and Sicily. Supporting this hypothesis, Montella et al. noted that the risk of classic KS was twofold higher among people born near Mount Vesuvius than among people born in neighbouring areas [19]. Interestingly, a magmatic substrate similar to that of the East African Rift system (extrusive igneous rocks composed of mafic (and hence iron oxide-rich) minerals) [20] is also present in Iceland and in the Faroe Islands which are other geographic areas known to exhibit surprisingly high incidence rates of classic KS [21]. One of the characteristics of these mafic minerals is that they are highly weatherable, allowing a significant release of iron compounds in the environment, such as in water or in vegetables [22]. The unusually high prevalence of the classic and endemic forms of KS in regions of intercontinental rifts and volcanism may thus point to prolonged exposure to indigenous iron oxide-rich volcanic soils as a common aetiological risk factor.

\section{Carcinogenic role of iron}

Several observations have been made linking cellular iron content to the development of cancers [23]. In prospective studies in animals, administration of excessive amounts of injected or oral iron increases markedly the risk of adenocarcinomas, colorectal tumours, hepatomas, mammary tumours, mesotheliomas, renal tubular cell carcinomas, and sarcomas [23]. In humans, injections of iron complexes have been observed to result in sarcomas at the sites of deposition [24]. Similarly, inhalation of industrial sources of iron may be responsible for respiratory tract neoplasias $[25,26]$. Patients with hemochromatosis, a genetic disease characterised by increased iron absorption, show a markedly enhanced susceptibility to primary liver cancer and various other malignancies [27]. Patients with moderate elevation of body iron levels may also have an increased risk of neoplasms of various kinds $[28,29]$.

The pathogenic role of iron in cancer development and/or progression is not fully understood. Several carcinogenic pathways have schematically been described: (a) iron is an essential element for dividing cells, because it is incorporated in numerous enzymes that play a role in DNA replication and cellular metabolism. More particularly, iron can directly promote the growth of some cancer cells [30], probably through its role in the activation of ribonucleotide reductase, a key-enzyme in DNA synthesis, responsible for the reduction of ribonucleotides to deoxyribonucleotides [31]; (b) iron may promote the formation of mutagenic hydroxyl radicals [23]; (c) iron excess diminishes host defences through inhibition of the 


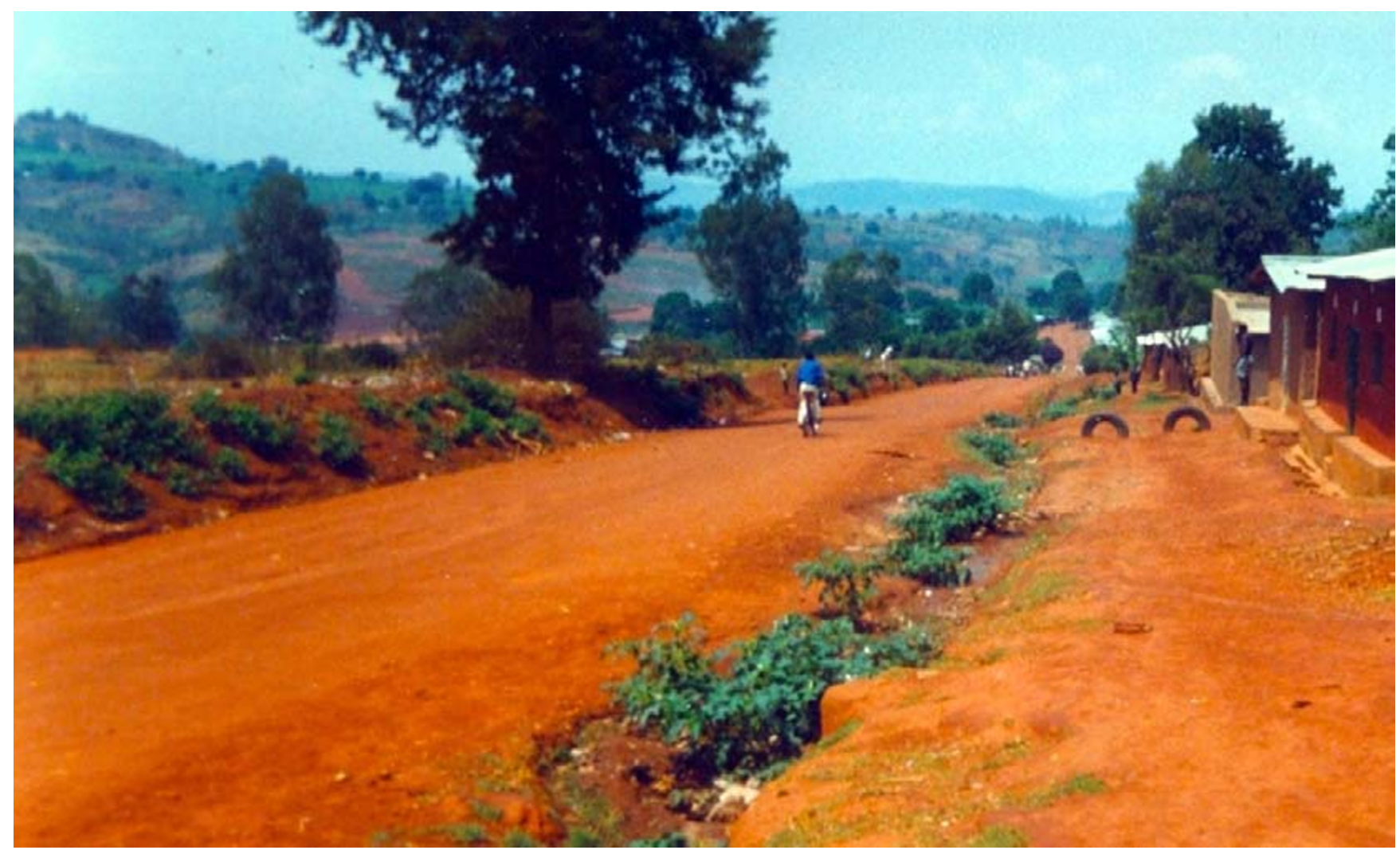

\section{Figure 2}

Landscape in the Kigali area (Rwanda): the red-brown colour of the soil is related to an intense weathering of the minerals of the geological substratum with massive release of fine particles of iron oxides and iron hydroxides.

activity of CD4 lymphocytes and through the suppression of the tumoricidal action of macrophages [23]; (d) iron can enhance host cell production of viral nucleic acids [32] which may be involved in the development of some human cancers. Other data support more specifically a direct role of iron in the pathogenesis of KS: 1) the addition of iron salts to KS-derived cells can stimulate their growth [33] ; 2) iron can induce the expression of antiapoptotic signals in human dermal microvascular endothelial cells [34], which may alter the homeostasis of microvessels and promote neo-angiogenesis. Interestingly, one of the histological hallmark of KS is the presence of ferritin granules and the presence of haemosiderin-laden macrophages (figure 3). Even at the early 'patch-stage' of KS development, red blood cell extravasation and the presence of siderophages are encountered, providing a possible continuous source of iron for endothelial and KS cells.

\section{Iron status in individuals prone to develop $K S$}

Amazingly, a high iron load is expected to be found in the different epidemiological forms of KS. Iron load is ele- vated in renal transplant recipients who had received blood transfusions for years before the availability of erythropoietin and before transplantation. Iron load could also be higher in patients with episodes of haemolytic anaemia which are common features in Central Africa or in Mediterranean areas, mostly secondary to glucose-6-phosphatase deficiency, thalassemia or sickle cell anaemia. In HIV infection, the alteration of iron metabolism has been recognised in a variety of ways [32]. The majority of patients in advanced stages of AIDS are hypoferrimic and moderately hyperferritinemic, and they have increased deposition of iron-ferritin and/or haemosiderin in cells of the bone marrow, brain white matter, skeletal muscle, and sometimes in the liver. The 'iron hypothesis' may also provide a non-hormonal explanation for the lower prevalence of KS among women, as they are known to have lower iron reserves than men. In this connection, it may also help to understand the reported disappearance of KS lesions during or just after pregnancy [35]. It is interesting to note that there are high incidence rates of KS among Bantu in the South African Transvaal [36] and that these individuals are known to frequently suffer from iron 


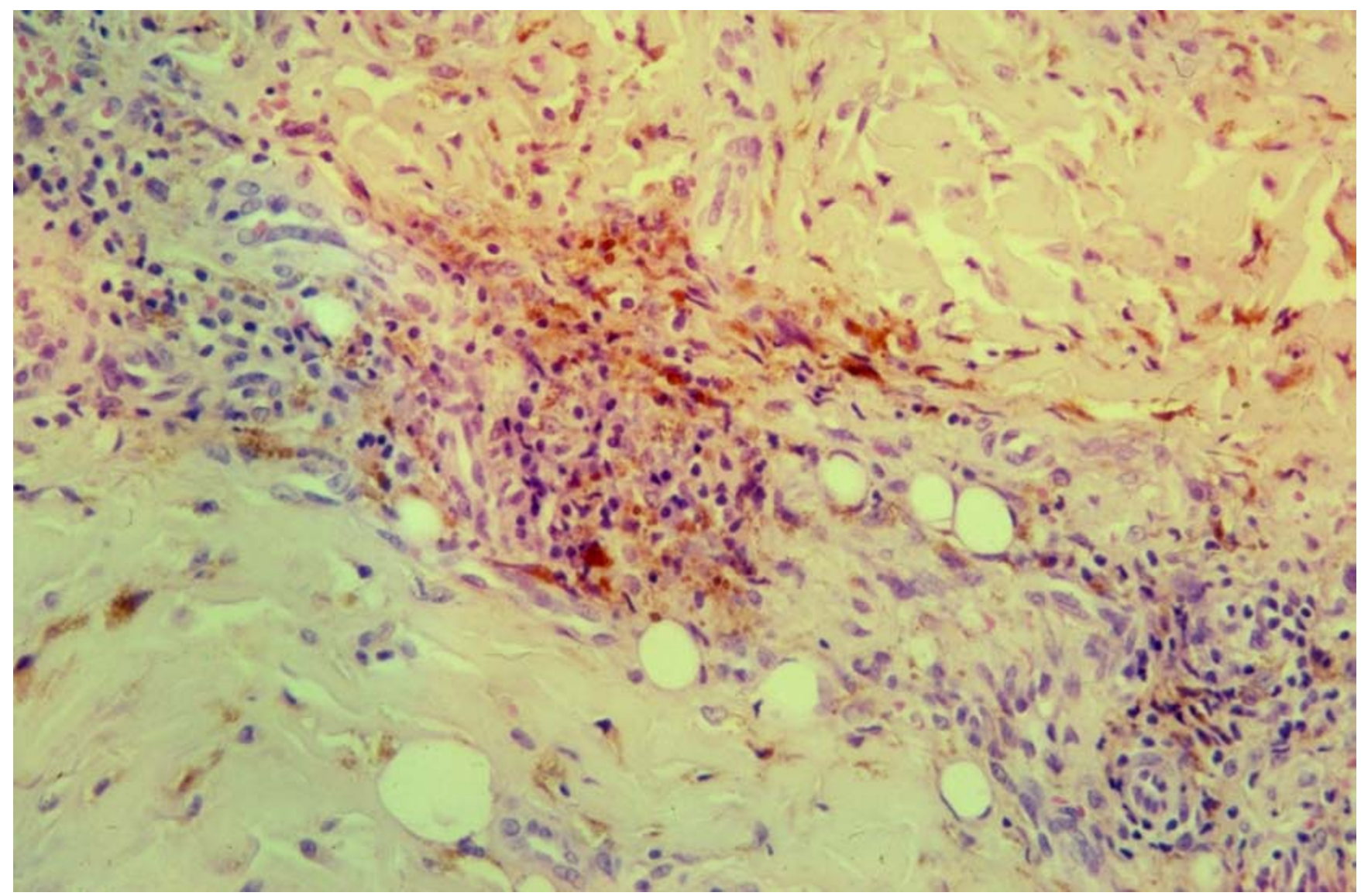

Figure 3

'Plaque-stage' KS showing the presence of numerous haemosiderin-laden macrophages.

overload resulting from the interaction between their genotype and an environmental factor - namely, increased amounts of bioavailable iron in the diet. The source of this dietary iron is a traditional fermented beer that is home-brewed from local crops in steel drums [37].

\section{Iron withdrawal strategies: a role for the management of KS?}

Based on a possible role of iron in tumour development, several studies have shown that iron withdrawal strategies possess considerable activity in vitro in inhibiting tumour growth [38,39]. More particularly, we found that the chemically unrelated iron chelators desferrioxamine (DFO) and deferiprone could inhibit the growth and induce the apoptosis of human KS-derived cells at clinically achievable concentrations [40], suggesting that iron chelation may represent an experimental therapeutic approach for the treatment of KS. Iron chelators have also been shown to inhibit vascular cell adhesion molecule-1 (VCAM-1) expression in human dermal microvascular cells [41]. As VCAM-1 may favour angiogenesis and account for inflammation-augmented tumour development $[42,43]$ and as it is used by cancer cells to enhance metastatic implantation and spread [42], VCAM-1 inhibition represents another mechanism through which iron chelation might prevent KS growth.

We previously initiated studies investigating the effect of DFO on the growth of immortalized KS-Y1 cells in immunodeficient mice, which resulted in paradoxical enhancement of the growth of the xenografts [44]. These results could be related to the upregulation of angiogenic growth factors by DFO [45] as well as to its short half-life in mouse plasma [46] and to its subsequent inability to induce significant iron depletion in non-iron-overloaded mice [44]. Another disadvantage of DFO is its poor ability to permeate cell membranes and bind intracellular $\mathrm{Fe}$ pools [47]. Obviously, investigation of iron chelators showing higher iron chelation and use of animal models closely mimicking human KS are required. 
Several chelators with greater antiproliferative and/or better pharmacokinetics than DFO have been recently developed [47]. Among the most promising molecules are the 2-pyridoxal isonicotinyl hydrazone (PIH) analogues [39]. Their antiproliferative activity is much greater than that of DFO and is comparable to that of bleomycin and cisplatin [48]. These molecules affect the expression of several molecules involved in cell cycle through their ability to chelate intracellular iron [39]. As PIH analogues may have potential as agents to treat cancer, they represent potential drugs for KS therapy. Another promising chelator with greater efficacy than DFO is ICL670A [49], which is an orally active representative of a new class of tridentate iron chelator developed for the treatment iron overload and which has been shown to be relatively well-tolerated in phase III studies [50]. Triapine, a ribonucelotide reductase inhibitor, has completed phase I studies in patients with advanced leukaemia and with advanced solid tumours $[51,52]$ and is currently in phase II clinical trial as an anticancer agent. CP502, GT56-252, NaHBED, and MPB0201 are examples of other new chelators in preclinical/clinical development [53].

Models closely mimicking human KS are obviously required to evaluate the effect of potential anti-KS drugs. Although there is currently no animal model that accurately represents KS pathogenesis, a number of mouse models have been established that attempt to address specific factors known to contribute to the development of the disease. In early studies, transformed KS cell lines such as KS Y-1 were injected into nude mice, which led to the development of KS-like lesions. This model was used to investigate the effect of various therapies on KS growth, such as human chorionic gonadotropin or interleukin-4 $[35,54]$. However, these xenografts models may be flawed, because none of the KS cells used for tumour establishment harbour HHV-8 sequences, as opposed to human KS lesions. More promising models have recently been obtained by creating transgenic mice expressing the HHV8-encoded chemokine receptor (viral G protein-coupled receptor) within hematopoietic cells [55]. The mice develop angioproliferative lesions in multiple organs that morphologically resemble KS lesions. These lesions are characterized by a spectrum of changes ranging from erythematous maculae to vascular tumours, by the presence of spindle and inflammatory cells, and by expression of vGPCR, CD34, and vascular endothelial growth factor [55]. In another model, HHV-8 was injected into normal human skin transplanted onto SCID mice. Injection of HHV-8 induced lesion formation that is morphologically and phenotypically consistent with KS, including the presence of angiogenesis and spindle-shaped cells latently infected with HHV-8 [56]. This in vivo system has the advantage of using human skin cells as the target of the virus, and may be the most accurate model of KS; how- ever, it does not completely mimic KS and is difficult to reproduce [57].

\section{Summary}

At present, several types of iron withdrawal strategies have been shown to possess considerable activity in vitro in inhibiting tumour growth. Based on the probable role of iron in KS pathogenesis, it is suggested that manipulations of iron load might interfere with tumour growth in patients with KS. However, further studies using potent iron chelators in suitable KS animal models are critical to evaluate whether iron deprivation may be a useful anti-KS strategy.

\section{Lists of abbreviations}

DFO: desferrioxamine

HHV-8: human herpesvirus-8

KS: Kaposi's sarcoma

VCAM-1: vascular cell adhesion molecule-1

\section{Competing interests}

None declared.

\section{Acknowledgements}

The author thanks Dr. P. Herbauts (Free University of Brussels, Belgium) for helpful comments regarding the geological data and Dr. P. Hermans (St. Pierre Hospital, Brussels, Belgium) for having provided the illustration for figure I.

\section{References}

I. Chang Y, Cesarman E, Pessin MS, Lee F, Culpepper J, Knowles DM, Moore PS: Identification of herpesvirus-like DNA sequences in AIDS-associated Kaposi's sarcoma. Science 1994, 266: $1865-1869$.

2. Noel JC, Hermans P, Andre J, Fayt I, Simonart T, Verhest A, Haot J, Burny A: Herpesvirus-like DNA sequences and Kaposi's sarcoma. Relationship with epidemiology, clinical spectrum, and histologic features. Cancer 1996, 77:2132-2136.

3. Antman K, Chang Y: Kaposi's sarcoma. N Engl J Med 2000, 342: 1027-1038.

4. Staskus KA, Zhong K, Bebhard B, Herndier B, Wang H, Renne R, Beneke J, Pudney J, Anderson DJ, Ganem D, Haase AT: Kaposi's sarcoma-associated herpesvirus gene expression in endothelial (spindle) tumor cells. J Virol 1997, 71:715-719.

5. Boschoff C, Schulz TF, Kennedy MM, Graham AK, Fisher C, Thomas A, McGee JO, Weiss RA, O'Leary J]: Kaposi's sarcoma-associated herpesvirus infects endothelial and spindle cell. Nature Med 1995, I:1274-1278.

6. Schulz TF, Sheldon J, Greensill J: Kaposi's sarcoma associated herpesvirus (KSHV) or human herpesvirus 8 (HHV8). Virus Res 2002, 82: II5-126.

7. Lenette ET, Blackbourn DJ, Levy JA: Antibodies to human herpesvirus type 8 in the general population and in Kaposi's sarcoma patients. Lancet 1996, 348:858-86I.

8. Chatlynne L, Ablashi D: Seroepidemiology of Kaposi's sarcomaassociated herpesvirus (KSHV). Semin Cancer Biol 1999, 9:175-185.

9. Gallo RC: The enigmas of Kaposi's sarcoma. Science 1998 , 282:1837-1839.

10. Dedicoat M, Newton R: Review of the distribution of Kaposi's sarcoma-associated herpesvirus (KSHV) in Africa in relation to the incidence of Kaposi's sarcoma. Br J Cancer 2003, 88: I-3. 
11. Biggar RJ, Whitby D, Marshall V, Linhares AC, Black F: Human herpesvirus 8 in Brazilian Amerindians: a hyperendemic population with a new subtype. J Infect Dis 2000, I 8 I: I $562-I 568$.

12. Taylor JF, Smith PG, Bull D, Pike MC: Kaposi's sarcoma in Uganda: geographic and ethnic distribution. Br J Cancer 1973, 26:483-495.

13. Cook-Mozaffari P, Newton R, Beral V, Bukitt DP: The geographical distribution of Kaposi's sarcoma and of lymphomas in Africa before the AIDS epidemic. Br J Cancer 1998, 78:152I-I528.

14. Ziegler JL: Endemic Kaposi's sarcoma in Africa and local volcanic soils. Lancet 1993, 342: I348-I35I.

15. Ziegler JL, Newton R, Katongole-Mbidde E, Mbulataiye S, De Cock K, Wabinga H, Mugerwa J, Katabira E, Jaffe H, Parkin DM, Reeves G, Weiss R, Beral V: Risk factors of Kaposi's sarcoma in HIV-positive subjects in Uganda. AIDS 1997, I I:1619-1626.

16. Ziegler JL, Newton R, Bourboulia D, Casabonne D, Beral V, Mbidde E, Carpenter L, Reeves G, Parkin DM, Wabinga H, Mbulaiteye S, Jaffe $H$, Weiss R, Boshoff C: Risk factors for Kaposi's sarcoma: a case-control study of HIV-seronegative people in Uganda. Int J Cancer 2003, I 03:233-240.

17. Price EW: Podoconiosis. Non-filarial elephantiasis. Oxford: Oxford University Press 1990.

18. Simonart T, De Dobbeleer G, Stallenberg B: Kaposi's sarcoma in a metallurgist: role of iron filings? $\mathrm{Br} J$ Dermatol 2003, | 48: 106|-1063.

19. Montella M, Franceschi S, Geddes M, Arniani S, Cocchiarella G: Classic Kaposi's sarcoma and volcanic soil in southern Italy. Lancet 1996, 347:905.

20. Krauskopf KB: Introduction to Geochemistry McGraw-Hill, Kogahusha Ltd: London; 1979.

21. Hialgrim $\mathrm{H}$, Tulinius $\mathrm{H}$, Dalberg J, Hardarson S, Frisch M, Melbye $M$ High incidence of classical Kaposi's sarcoma in Iceland and the Faroe Islands. Br J Cancer 1998, 77: I I90- I I93.

22. Ollier C: Weathering Longman Group Ltd: Essex; 1984.

23. Weinberg ED: The role of iron in cancer. Eur J Cancer Prev 1996 5:19-36.

24. Ludin PM: The carcinogenic action of complex iron preparations. $\mathrm{Br}$ J Cancer 196I, I 5:838-847.

25. Dreyfus JR: Lungencarcinoma bei Geschwisteern nach Inhalation von eisenoxydaltigem Staub in der Jugend. Zeit Klin Med 1936, 130:256-260.

26. Sherson D, Svane O, Lynge E: Cancer incidence among foundry workers in Denmark. Arch Environ Health 1991, 46:75-81.

27. Hsing AW, McLaughlin JK, Olsen JH, Mellemkjar L, Wacholder S, Fraumeni JF Jr: Cancer risk following primary haemochromatosis: a population-based cohort study in Denmark. Int J Cancer 1995, 60:160-162.

28. Knekt $P$, Reuanen $A$, Takkunen $H$, Aromaa A, Heliovaara $M$, Hakulinen T: Body iron stores and risk of cancer. Int J Cancer 1994, 56:379-382.

29. Stevens RG, Graubard BI, Micozzi MS, Neriishi K, Blumberg BS: Moderate elevation of body iron level and increased risk of cancer occurrence and death. Int / Cancer 1994, 56:364-369.

30. Cazzola M, Bergamaschi G, Dezza L, Arosio P: Manipulations of cellular iron metabolism for modulating normal and malignant cell proliferation. Blood 1990, 75:1903-1919.

31. Reichard P, Ehrenberg A: Ribonucleotide reductase: $A$ radical enzyme. Science 1983, $221: 514-519$.

32. Boelaert JR, Weinberg GA, Weinberg ED: Altered iron metabolism in HIV infection: mechanisms, possible consequences, and proposals for management. Infect Agents Dis 1996, 5:36-46.

33. Simonart T, Noel JC, Andrei G, Parent D, Van Vooren JP, Hermans $P$, Lunardi-Yskandar Y, Lambert C, Dieye T, Farber CM, Liesnard C, Snoeck R, Heenen M, Boelaert JR: Iron as a potential cofactor in the pathogenesis of Kaposi's sarcoma. Int J Cancer 1998, 78:720-726.

34. Simonart T, Degraef C, Stordeur P, Noel JC, Mosselmans R, Van Vooren JP, Parent D, Boelaert JR, Heenen M, Galand P: Iron induces bcl-2 expression in human dermal microvascular endothelial cells. Free Rad Res 2001, 34:221-235.

35. Lunardi-Iskandar Y, Bryant JL, Zeman RA, Lam VH, Samaniego F, Besnier JM, Hermans P, Thierry AR, Gill P, Gallo RC: Tumorigenesis and metastasis of neoplastic Kaposi's sarcoma cell line in immunodeficient mice blocked by a human pregnancy hormone. Nature 1995, 375:64-68.
36. Oettle AG: Geographical and racial differences in the frequency of Kaposi's sarcoma as evidence of environmental or genetic causes. Acta Un Int Cancr 1962, I 8:330-363.

37. Gordeuk VR, Boyd RD, Brittenham GM: Dietary iron overload persists in rural sub-Saharan Africa. Lancet I986, I:I3 I0- I3 I3.

38. Weinberg ED: Development of clinical methods of iron deprivation for suppression of neoplastic and infectious diseases. Cancer Invest 1999, I 7:507-5 I3

39. Gao J, Richardson DS: The potential of iron chelators of the pyridoxal isonicotinoyl hydrazone class as effective antiproliferative agents, IV: the mechanisms involved in inhibiting cell-cycle progression. Blood 200I, 98:842-850.

40. Simonart T, Degraef C, Andrei G, Mosselmans R, Hermans P, Van Vooren JP, Noel JC, Boelaert JR, Snoeck R, Heenen M: Iron chelators inhibit the growth and induce the apoptosis of Kaposi's sarcoma cells and of their putative endothelial precursors. Invest Dermatol 2000, I I 5:893-900.

4I. Simonart $\mathrm{T}$ : Inhibition of vascular cell adhesion molecule-I expression in human dermal microvascular endothelial cells by iron chelators. J Invest Dermatol 2003, I 2 I : I I29-30.

42. Vidal-Vanaclocha F, Fantuzzi G, Mendoza L, Fuentes AM, Anasagasti MJ, Martin J, Carrascal T, Walsh P: IL-I 8 regulates IL-Ibetadependent hepatic melanoma metastasis via vascular cell adhesion molecule-I. Proc Natl Acad Sci USA 2000, 97:734-739.

43. Nakao S, Kuwano T, Ishibashi T, Kuwano M, Ono M: Synergistic effect of TNF-alpha in soluble VCAM-I-induced angiogenesis through alpha(4) integrins. J Immunol 2003, I 70:5704-57 I I.

44. Simonart T, Boelaert JR, Andrei G, van den Oord J, Degraef $C$, Hermans P, Noel JC, Van Vooren JP, Heenen M, De Clercq E, Snoeck R: Desferrioxamine enhances AIDS-associated Kaposi's sarcoma tumor development in a xenograft model. Int J Cancer 2002, 100:140-143.

45. Beerepoot LV, Shima DT, Kuroki M, Yeo KT, Voest EE: Up-regulation of vascular endothelial growth factor production by iron chelation. Cancer Res 1996, 56:3747-375I.

46. Meyer-Brunot HG, Keberle $H$ : The metabolism of desferrioxamine B and ferrioxamine B. Biochem Pharmacol 1967 16:527-535.

47. Lovejoy DB, Richardson DR: Iron chelators as anti-neoplastic agents: current developments and promise of the PIH class of chelators. Curr Med Chem 2003, I 0:1035-1049.

48. Richardson DR, Milnes K: The potential of iron chelators of the pyridoxal isonicotinoyl hydrazone class as effective antiproliferative agents II: the mechanism of action of ligands derived from salicylaldehyde benzoyl hydrazone and 2 hydroxy-I-naphthylaldehyde benzoyl hydrazone. Blood 1997, 89:3025-3038.

49. Galanello $R$, Piga A, Alberti D, Rouan MC, Bigler $H$, Sechaud $R$ Safety, tolerability, and pharmacokinetics of ICL670, a new orally active iron-chelating agent in patients with transfusion-dependent iron overload due to beta-thalassemia. J Clin Pharmacol 2003, 43:565-572.

50. Nisbet-Brown E, Olivieri NF, Giardina PJ, Grady RW, Neufeld EJ, Sechaud R, Krebs-Brown AJ, Anderson JR, Alberti D, Sizer KC, Nathan DG: Effectiveness and safety of ICL670 in iron-loaded patients with thalassaemia: a randomised, double-blind, placebo-controlled, dose-escalation trial. Lancet 2003, 36 I: 1597-1602.

5I. Murren J, Modiano M, Clairmont C, Lambert P, Savaraj N, Doyle T, Sznol M: Phase I and pharmacokinetic study of triapine, a potent ribonucleotide reductase inhibitor, administered daily for five days in patients with advanced solid tumors. Clin Cancer Res 2003, 9:4092-4100.

52. Giles FJ, Fracasso PM, Kantariian HM, Cortes JE, Brown RA, Ver stovsek S, Alvarado Y, Thomas DA, Faderl S, Garcia-Manero G, Wright LP, Samson T, Cahill A, Lambert P, Plunkett W, Sznol M, DiPersio JF, Gandhi V: Phase I and pharmacodynamic study of Triapine, a novel ribonucleotide reductase inhibitor, in patients with advanced leukemia. Leuk Res 2003, 27:1077-83.

53. Tam TF, Leung-Toung R, Li W, Wang Y, Karimian K, Spino M: Iron chelator research: past, present, and future. Curr Med Chem 2003, 1 0:983-995.

54. Husain SR, Kreitman RJ, Pastan I, Puri RK: Interleukin-4 receptordirected cytotoxin therapy of AIDS-associated Kaposi's sarcoma tumors in xenograft model. Nat Med 1999, 5:817-22. 
55. Yang TY, Chen SC, Leach MW, Manfra D, Homey B, Wiekowski M, Sullivan L, Jenh CH, Narula SK, Chensue SW, Lira SA: Transgenic expression of the chemokine receptor encoded by human herpesvirus 8 induces an angioproliferative disease resembling Kaposi's sarcoma. J Exp Med 2000, 19 I:445-54.

56. Foreman KE, Friborg J, Chandran B, Katano H, Sata T, Mercader M, Nabel GJ, Nickoloff BJ: Injection of human herpesvirus-8 in human skin engrafted on SCID mice induces Kaposi's sarcoma-like lesions. J Dermatol Sci 200I, 26:182-93.

57. Bubman D, Cesarman E: Pathogenesis of Kaposi's sarcoma. Hematol Oncol Clin N Am 2003, 17:717-745.

\section{Pre-publication history}

The pre-publication history for this paper can be accessed here:

http://www.biomedcentral.com/1471-2407/4/1/prepub

Publish with Bio Med Central and every scientist can read your work free of charge

"BioMed Central will be the most significant development for disseminating the results of biomedical research in our lifetime. "

Sir Paul Nurse, Cancer Research UK

Your research papers will be:

- available free of charge to the entire biomedical community

- peer reviewed and published immediately upon acceptance

- cited in PubMed and archived on PubMed Central

- yours - you keep the copyright

Submit your manuscript here:

http://www.biomedcentral.com/info/publishing_adv.asp 